\title{
STRUKTUR KOMUNITAS MANGROVE DI DESA BONE BARU, KECAMATAN BANGGAI UTARA, KABUPATEN BANGGAI LAUT, SULAWESI TENGAH
}

\author{
(Mangrove Community Structure at Bone Baru Village, Sub-District of Banggai \\ Utara, District of Banggai Laut, Central Sulawesi)
}

\author{
Prengky P. Babo ${ }^{\star *}$, Calvyn F.A. Sondak ${ }^{1}$, James J.H. Paulus ${ }^{1}$, Joshian N.W. Schaduw ${ }^{1}$, Ping Astony \\ Angmalisang ${ }^{1}$, Adnan S. Wantasen ${ }^{2}$
}

${ }^{1}$ Program Studi IImu Kelautan, FPIK UNSRAT Manado.

2Program Studi Manajemen Sunberdaya Perairan, FPIK UNSRAT Manado.

*e-mail : frengkibabo@.Yahoo.com

\begin{abstract}
Mangrove is one of plants that can grow well on the coast which are affected by tides.Bone Baru village is located in North Banggai District, Banggai Laut Regency, Central Sulawesi Province which has area that about 840 ha and has mangrove area reaching 16.56 ha. This research was conducted from February to April 2020. The purpose of this research are to identify the types of mangroves and analyzing the structure of the mangrove community which include density, relative density, frequency, relative frequency, coverarge, relative coverage, importance value index, and diversity index. The data were analyzed using Microsoft Excel. Based on the results this study obtained 4 types of mangroves consisting of Bruguiera gymnorrhiza, B. cylindrica, Rhizophora mucronata, and Lumnitzera littorea. The highest relative density was $0.13 \mathrm{ind} / \mathrm{m}^{2}$ and the relative density was $91.83 \%$ the highest frequency type and the frequency relative value were 5 ind / m2 and $52.63 \%$ respectively. The highest mangrove cover was $3.79 \mathrm{~m}^{2}$ with relative cover of $52.21 \%$. The highest important value index was $227.72 \%$. The highest diversity index was found at station 2 with an average value $\left(\mathrm{H}^{\prime}\right)$ of 0.69 .
\end{abstract}

Keywords: mangrove, community structure, habitat, Banggai

\section{ABSTRAK}

Mangrove merupakan kelompok tumbuhan yang dapat tumbuh dengan baik di pesisir pantai yang dipengaruhi oleh pasang surut air laut. Penelitian ini dilakukan di desa Bone Baru, Kecamatan Banggai Utara, Kabupaten Banggai Laut, Provinsi Sulawesi Tengah yang memiliki luas wilayah mencapai 840 ha dan memiliki luas area mangrove mencapai 16,56 ha. Penelitian ini dilakukan dari bulan Februari-April 2020 dengan menggunakan metode Line Transect. Tujuan dari penelitian ini adalah mengidentifikasi jenis-jenis mangrove dan menganalisa struktur komunitas mangrove Data yang diambil meliputi kerapatan jenis, kerapatan relatif jenis, frekuensi jenis, frekuensi relatif jenis, penutupan jenis, penutupan relatif jenis, indeks nilai penting, dan indeks keanekaragaman yang kemudian di analisa dengan bantuan program komputer Microsoft Excel. Berdasarkan hasil penelitian ditemukan 4 jenis mangrove yaitu Bruguiera gymnorrhiza, Rhizophora mucronata, Lumnitzera littorea dan Bruguiera cylindrica. Kerapatan jenis tertinggi $0,13 \mathrm{ind} / \mathrm{m}^{2}$ dan kerapatan relatifnya $91,83 \%$. Frekuensi jenis tertinggi dengan nilai $5 \mathrm{ind} / \mathrm{m}^{2}$ relatifnya $52,63 \%$, penutupan jenis tertinggi dengan nilai $3,79 \mathrm{~m}^{2}$ dan relatfnya $52,21 \%$, indeks nilai penting tertinggi dengan nilai $227,72 \%$ dan Nilai indeks keanekaragaman tertinggi ditemukan pada stasiun 2 dengan nilai ratarata $\left(H^{\prime}\right) 0,69$.

Kata kunci: mangrove, strukture komunitas, habitat, Banggai 


\section{PENDAHULUAN}

Mangrove adalah jenis tumbuhan tropis maupun sub tropis yang mampu bertahan hidup pada kadar salinitas air yang relatif tinggi dan substrat berlumpur. Secara bioekologis, hutan mangrove mempunyai peranan yang penting dalam ekosistem pantai yaitu sebagai penyediaan bahan organik, tempat asuhan (nursery ground), tempat bertelur (spawning ground), dan tempat berlindung berbagai biota laut, serta sebagai pelindung pantai dari aktivitas gelombang (Wantasen, 2013). Paulus, dkk. (2020) menyimpulkan bahwa Tingginya kandungan Cadmium pada titik pusat terkonsentrasinya perakaran Mangrove, telah mengungkapkan kemampuan Mangrove dengan sistem perakarannya serta menyimpan logam pada sedimen. Selain itu, Hutan mangrove berperan dalam upaya mitigasi akibat dari pemanasan global karena mangrove dapat berfungsi sebagai penyimpan karbon (C) (Sondak, 2015). Paulus, dkk. (2015), menyatakan bahwa beberapa Serangga tersebar di beberapa daerah di indonesia terutama pada area bakau, mangrove dijadikan sebagai tempat tinggal dan cocok untuk mencari makan dan bertelur bagi serangga.

Spesies mangrove yang ditemukan di wilayah Indonesia termasuk dalam dua kelompok wilayah biogeografi belahan bumi bagian timur yakni: Indo-Malesia dan Asia, Australasia dan Pacific Barat (Duke, dkk. 1992 dalam Djamaluddin, 2018). Sekitar 202 jenis bakau di Indonesia telah teridentifikasi serta tumbuh dengan subur (Noor, dkk. 2006). Beberapa jenis mangrove yang umum dijumpai di Indonesia adalah bakau (Rhizophora), api-api (Avicennia), pedada (Sonneratia), tanjang (Bruguiera) dan nyirih (Xylocarpus).
Tujuan penelitian ini adalah mengetahui struktur komunitas yang meliputi komposisi dari vegetasi mangrove secara kuantitatif seperti jumlah, jenis, kerapatan jenis, frekuensi jenis, penutupan jenis, nilai penting dan keanekaragaman maupun pola sebarannya. Melihat begitu pentingnya peranan ekosistem mangrove serta masih sedikitnya data mengenai struktur komunitas mangrove di Kabupaten Banggai Laut, maka dilaksanakan penelitian mengenai jumlah populasi vegetasi mangrove di Desa Bone Baru, Kecamatan Banggai Utara. Penelitian ini merupakan salah satu aspek penting untuk mengetahui kondisi suatu ekosistem pesisir serta dapat memberikan Pemahaman dan kepedulian dari Pemerintah Daerah Kabupaten Banggai Laut terhadap kelengkapan data-data mengenai status Hutan Mangrove yang ada di Kabupaten Banggai Laut.

\section{METODE PENELITIAN}

\section{Tempat dan Waktu Penelitian}

Penelitian ini dilaksanakan di desa Bone Baru Kecamatan Banggai Utara Kabupaten Banggai Laut Provinsi Sulawesi Tengah dari bulan Februari sampai April 2020. Desa Bone Baru adalah salah satu desa yang berada di Kabupaten Banggai Laut yang terletak di Kecamatan Banggai Utara. Secara geografis Desa Bone Baru berada pada titik koordinat yaitu $01^{\circ} 31^{\prime} 56.9 " \mathrm{LS}$, $123^{\circ} 29^{\prime} 25.5$."BT yang merupakan salah satu desa di Kecamatan Banggai Utara yang mempunyai luas wilayah mencapai $8,4 \mathrm{~km}^{2}$, Desa Bone Baru terletak di sebelah Barat Kecamatan Banggai Utara. Secara administratif, Desa Bone Baru merupakan sebuah desa yang termasuk dalam wilayah Kabupaten Banggai Laut, Provinsi Sulawesi Tengah. peta lokasi penelitian dapat dilihat pada Gambar 1. 


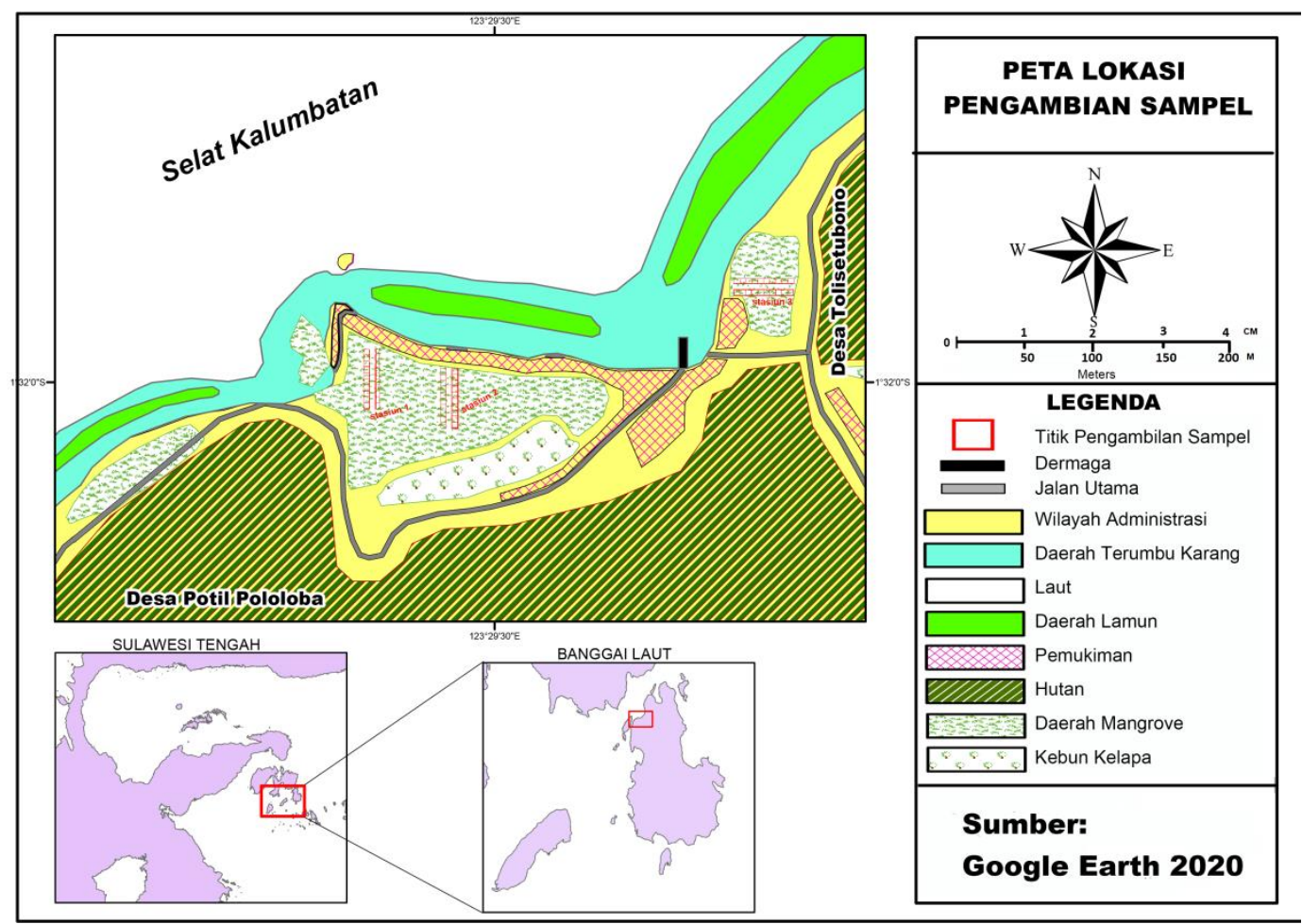

Gambar 1 : Peta Lokasi Penelitian

\section{Alat dan Bahan Penelitian}

Tabel 1. Alat dan Bahan beserta kegunaan

\begin{tabular}{|c|c|}
\hline Alat dan Bahan & Kegunaan \\
\hline $\begin{array}{l}\text { - } \quad \text { Buku identifikasi mangrove } \\
\text { (Pengenalan dan Pengelolaan } \\
\text { Ekosistem Mangrove) }\end{array}$ & $\begin{array}{l}\text { Buku untuk mengidentifikasi } \\
\text { jenis mangrove }\end{array}$ \\
\hline - $\quad$ Tali Rafiah & Membentuk transek Wilayah \\
\hline - $\quad$ Alat Tulis & Mencatat hasil pengukuran \\
\hline - Kamera & Dokumetasi \\
\hline $\begin{array}{l}\text { GPS (Global Positioning System) } \\
\text { /Handphone }\end{array}$ & $\begin{array}{l}\text { Merekam titik } \quad \text { koordinat } \\
\text { stasiun }\end{array}$ \\
\hline - $\quad$ Meteran Rol & Mengukur panjang transek \\
\hline - $\quad$ Meteran $150 \mathrm{~cm}$ & $\begin{array}{l}\text { Mengukur keliling lingkar } \\
\text { batang pohon }\end{array}$ \\
\hline
\end{tabular}




\section{Teknik Pengambilan Data}

Metode yang digunakan dalam penelitian adalah metode line transect. Line transect method merupakan metode pencuplikan contoh populasi vegetasi dalam suatu ekosistem dengan melakukan pendekatan petak contoh yang berada pada garis yang dibuat melewati wilayah ekosistem. Line transect ditarik sepanjang 50-100 meter pada setiap stasiun kemudian pada setiap transek diletakan/ditempatkan kuadran berukuran 10mx10m (Dharmawan dan Pramudji, 2014; English et al. 1997 dalam Schaduw, 2019) dan Dalam setiap plot, $10 \mathrm{~m} \times 10 \mathrm{~m}$ dilakukan pengukuran diameter batang pohon mangrove (diameter $>4 \mathrm{~cm}$ atau keliling batang $>16 \mathrm{~cm}$ ) (Ashton dan Mclntosh, 2002 dalam Dharmawan dan Pramudji, 2014) dengan menggunakan meteran pada variasi letak pengukuran berdasarkan English et al. (1997) dalam Dharmawan dan Pramudji (2014) dan Keputusan Menteri Lingkungan Hidup RI No. 201 tahun 2004 tentang Kriteria Baku dan Pedoman Penentuan Kerusakan Mangrove. Garis transek ditarik dengan arah tegak lurus dari pantai arah utara ke selatan kearah darat dan dari arah barat ke arah timur sepanjang 100 meter adanya mangrove, jarak antar stasiun 1 dan 2 adalah $50 \mathrm{~m}$ dan jarak antar stasiun 2 dan 3 adalah kurang lebih $100 \mathrm{~m}$, dan jarak antara transek di tiap stasiun adalah $25 \mathrm{~m}$.

\section{Analisis Data}

Analisis vegetasi mangrove menggunakan rumus dari (English et al., 1994 dalam Parmadi, dkk. 2016) sebagai berikut :
a) Kerapatan jenis (Di)
$\mathrm{D}_{\mathrm{i}}=\frac{n i}{A}$
$D i=$ kerapatan spesies ke $\mathrm{i}$
$n i=$ jumlah total individu spesies ke $\mathrm{i}$
$A=$ luas area total pengambilan contoh

b) Kerapatan Relatif Jenis (RDi)

$\mathrm{RDi}=\left(\frac{n i}{\sum n}\right) \times 100$

$(\mathrm{RDi})=$ Kerapatan relatif spesies ke $\mathrm{i}$

(ni) = Jumlah individu Spesies ke i

\section{c) Frekuensi Jenis (Fi)}

$\mathrm{Fi}=\left(\frac{p i}{\sum p}\right)$

$\mathrm{Fi}=$ Frekuensi spesies ke $\mathrm{i}$

$\mathrm{Pi}=$ Jumlah petak contoh dimana ditemukan spesies ke i

\section{d) Frekuensi Relatif Jenis (RFi)}

$\mathrm{RFi}=\left(\frac{F i}{\sum F}\right) \times 100$

$\mathrm{RFi}=$ Frekuensi relatif spesies ke $\mathrm{i}$

$\mathrm{Fi}=$ Frekuensi spesies ke $\mathrm{i}$

e) Penutupan Jenis (Ci)

$\mathrm{Ci}=\left(\frac{\sum B A}{A}\right)$

$\mathrm{BA}=\left(\frac{\pi \mathrm{DBH} 2}{4}\right)$ dalam $\left(\mathrm{Cm}^{2}\right)$

$\mathrm{BA}=\pi \mathrm{DBH} 2: 4$ (dalam Cm2)

$\pi=$ konstanta $(3,14)$

$\mathrm{DBH}=$ diameter pohon dari jenis ke $\mathrm{i}$

$A=$ luas area total pengambilan contoh (luas total petak/plot/kuadrat)

$\mathrm{DBH}=\mathrm{CBH} / \pi$ (dalam $\mathrm{Cm}$ ), $\mathrm{DBH}$ adalah lingkaran pohon setinggi dada

\section{f) Penutupan Relatif Jenis ( $\mathrm{RCi}$ )}

$R C i=\left(\frac{C i}{\sum C}\right) \times 100$

$\mathrm{RCi}=$ Penutupan relatif spesies dan luas total area

$\mathrm{Ci}=$ Luas area penutupan spesies ke $\mathrm{i}$

g) Indeks Nilai Penting (INP)

Nilai Penting suatu jenis berkisar antara $0 \%$ sampai $300 \%$. Indeks Nilai Penting memberikan suatu gambaran mengenai pengaruh atau peranan suatu jenis tumbuhan mangrove terhadap komunitas mangrove. Indeks Nilai Penting adalah kerapatan relatif jenis (RDi), frekuensi relatif jenis (RFi) dan penutupan relatif jenis $(\mathrm{RCi})$.

$\mathrm{INP}=\mathrm{RDi}+\mathrm{RFi}+\mathrm{RCi}$

\section{h) Indeks Keanekaragaman}

Indeks keanekaragaman adalah ukuran kekayaan komunitas dilihat dari jumlah spesies dalam suatu kawasan beserta jumlah individu dari setiap spesies. 
$H^{\prime}=-\sum_{i-1}^{S} P i \ln P i$

$H^{\prime}=$ Indeks keanekaragaman ShannonWiener

$\mathrm{N}=$ Jumlah total individu dalam komunitas $\left(\sum n i\right)$

$\mathrm{ni}=$ Jumlah individu spesies atau jenis ke-i

$\mathrm{Pi}=$ Proporsi individu spesies ke-i (ni/N)

HASIL DAN PEMBAHASAN

Jenis-jenis Mangrove di kawasan Pesisir

Desa Bone Baru, Kecamatan Banggai

Utara, Kabupaten Banggai Laut

Berdasarkan hasil penelitian yang dilakukan pada ketiga stasiun ditemukan 4 spesies mangrove yaitu Bruguiera gymnorrhiza, Rhizophora mucronata, Lumnitzera littorea dan Bruguiera cylindrica.
Jenis yang paling banyak ditemukan dilokasi penelitian adalah jenis mangrove $R$. mucronata yang memiliki ciri-ciri antara lain pohon dengan ketinggian mencapai $27 \mathrm{~m}$ dengan kulit kayu berwarna gelap hingga hitam dan terdapat celah horizontal. Akar tunjang dan akar udara yang tumbuh dari percabangan bagian bawah, memiliki daun berbentuk elips melebar hingga bulat memanjang dengan ujung meruncing, memiliki bunga dengan daun mahkota 4 berwarna putih dan 8 benang sari tak bertangkai, dan memiliki Buah berbentuk lonjong/panjang hingga berbentuk telur berukuran 5-7 cm, berwarna hijaukecoklatan seringkali kasar di bagian pangkal, berbiji tunggal (Noor, dkk. 2006).
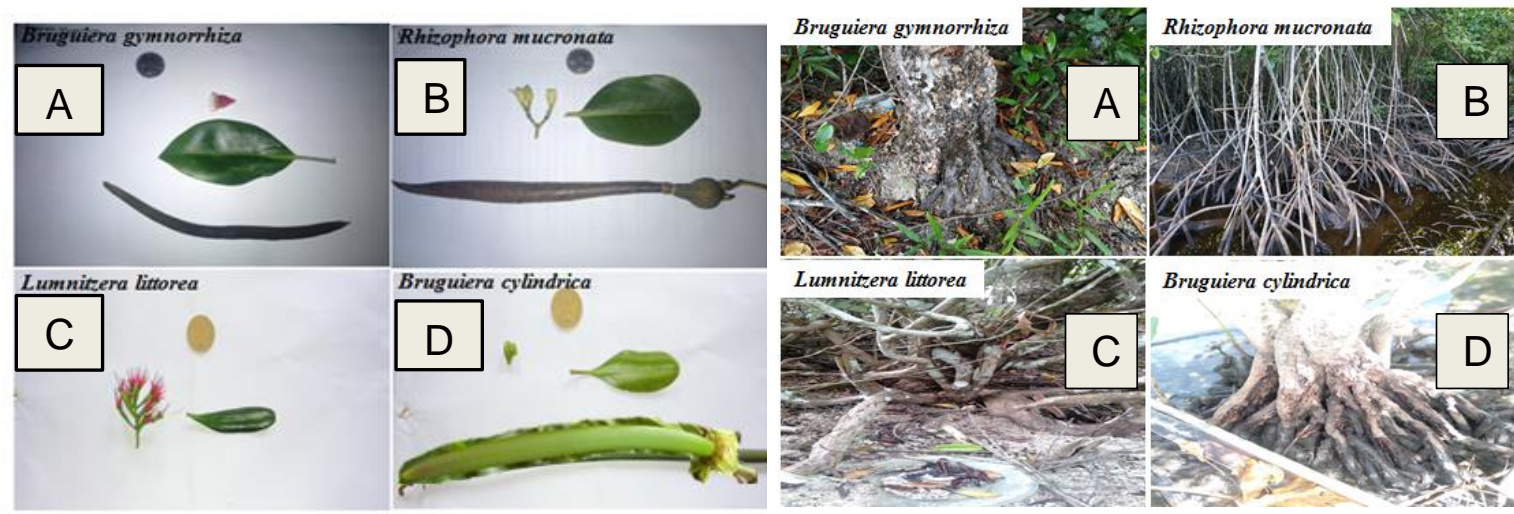

Gambar 2. (A) Bentuk akar, Daun, Bunga dan Buah dari spesies Bruguiera gymnorrhiza

(B) Bentuk akar, Daun, Bunga dan Buah dari spesies Rhizophora mucronata

(C) Bentuk akar, Daun, Bunga dandari spesies Lumnitzera littorea

(D) Bentuk akar, Daun, Bunga dan Buah dari spesies Bruguiera cylindrica

(Dokumen Pribadi, 2020)

Analisis Struktur Komunitas Mangrove Kerepatan jenis dan kerapatan relatif jenis

Kerapatan jenis mangrove adalah jumlah tegakan jenis i dalam suatu area sedangkan kerapatan relatif jenis mangrove adalah perbandingan antara jumlah tegakkan jenis i dengan jumlah total tegakkan seluruh jenis (Bengen, 2000). Nilai kerapatan tertinggi terdapat di stasiun 1 transek 2 jenis $R$. mucronata dengan nilai $0,13 \mathrm{ind} / \mathrm{m}^{2}$ relatifnya $91,83 \%$ sedangkan nilai kerapatan terendah terdapat distasiun 1 transek 1 dan 2 jenis $L$. littorea $0,007 \mathrm{ind} / \mathrm{m}^{2}$ relatifnya $5,93 \%$ dan $B$. cylindrica $0,002 \mathrm{ind} / \mathrm{m}^{2}$ relatifnya $1,36 \%$. Kerapatan jenis mangrove untuk setiap transek dapat dilihat pada (Gambar 3 dan 4).

Tingginya nilai kerapatan jenis ditentukan oleh banyaknya jumlah individu, begitu pula sebaliknya jika jumlah individunya sedikit maka nilai kerapatannya rendah. Pada penelitian Asman, dkk. (2020) di Desa Lesah degan kondisi substrat pasir berlumpur yang sama, nilai kerapatan tertinggi yaitu 0.122 ind $/ \mathrm{m} 2$ relatifnya $81.88 \%$, Kondisi yang sama 
terdapat juga di Desa Arakan pada penelitian Iskandar, dkk. (2019) kerapatan jenis tertinggi pada yaitu 0.710 ind $/ \mathrm{m} 2$ relatifnya $97.26 \%$. Selain itu pada penelitian Bacmid, dkk. (2019) di Kelurahan Alung Benua didapatkan Nilai kerapatan tertinggi yaitu $0.16 \mathrm{ind} / \mathrm{m} 2$ relatifnya 88.89\%. Pada penelitian Jacobs, dkk. (2019) di Desa Lamanggo dan Desa Tope, Kecamatan Biaro nilai kerapatan tertinggi yaitu $0.25 \mathrm{ind} / \mathrm{m}^{2}$ dengan nilai kerapatan relatif 47.17\%. Pada penelitian Ontorael, dkk. (2012) Di Desa Tarohan Selatan Kecamatan Beo Selatan Kabupaten Kepulauan Talaud, nilai kerapatan jenis tertinggi yaitu $0,0176 \mathrm{ind} / \mathrm{m}^{2}$ dengan nilai relatifnya $68,75 \%$

Berdasarkan beberapa penelitian menunjukan bahwa Kerapatan jenis tertinggi disebabkan oleh subsrat yang cocok, dan kemampuan beradaptasi dengan kondisi lingkungan dan faktor yang menyebabkan pertumbuhan mangrove relatif jarang adalah kondisi akar pohon yang tergolong besar sehingga pertumbuhan mangrove tersebut menjadi kurang optimal (Agustini, dkk. 2016). Setyawan, dkk. (2005) mengatakan bahwa spesies mangrove memiliki tingkat adaptabilitas yang tinggi terutama pada jenis tertentu seperti propagul pada jenis Rhizophora sp umumnya telah tumbuh sejak masih menempel pada batang induknya (vivipar) sehingga tingkat keberhasilan pertumbuhan menjadi lebih besar, selain itu pada jenis $R$. mucronata memiliki bentuk propagul yang jauh lebih besar dengan cadangan makanan yang lebih banyak, sehingga memiliki kesempatan hidup lebih tinggi dan dapat disebarkan oleh arus air laut secara luas.

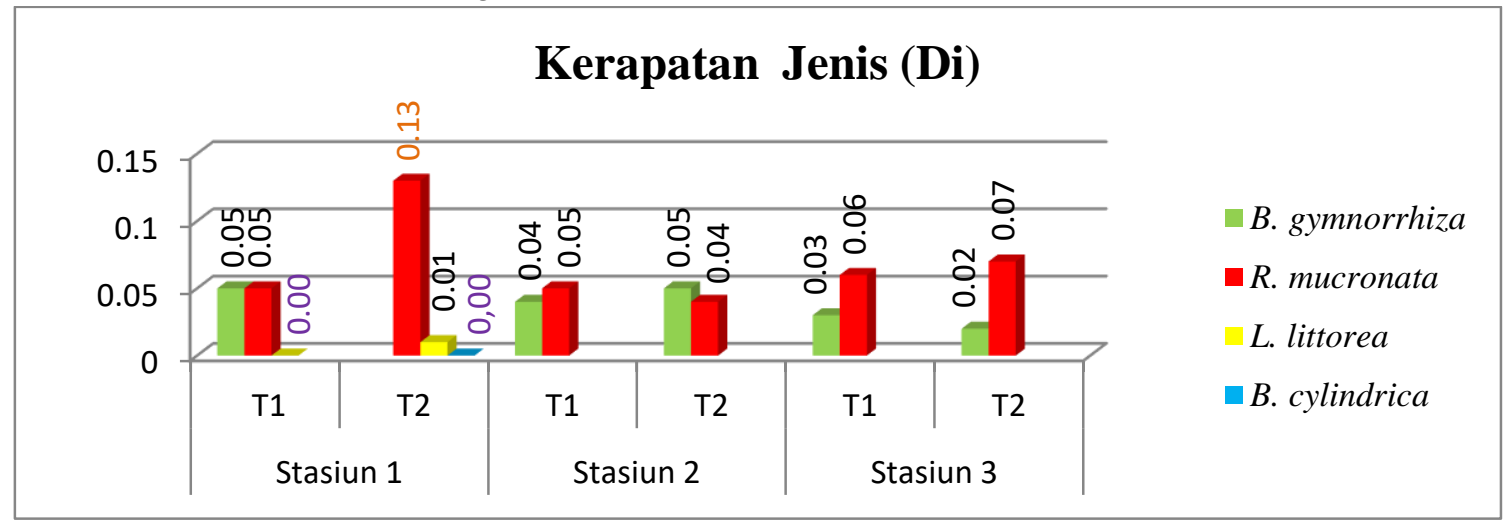

Gambar 3. Kerapatan Jenis (Di)

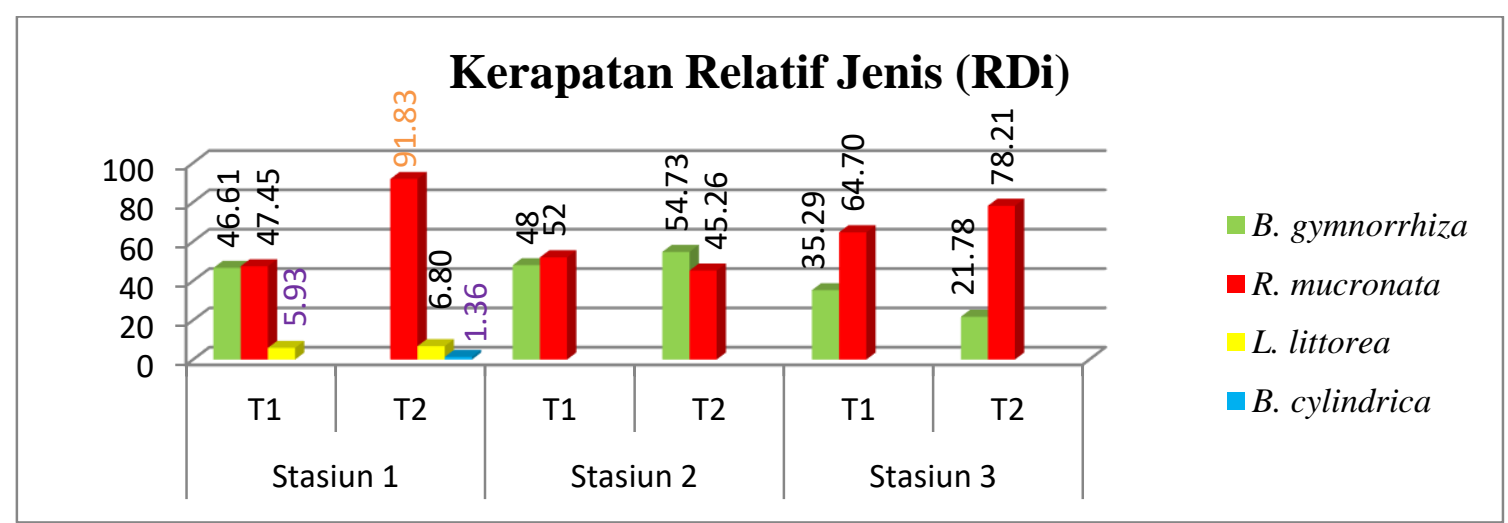

Keterangan warna nilai :

Nilai Tertinggi

Nilai Terendah

Gambar 4. Kerapatan Relatif Jenis (RDi) 


\section{Frekuensi jenis dan frekuensi relatif jenis}

Frekuensi jenis adalah peluang ditemukannya jenis ke i dalam petak contoh/plot yang diamati sedangkan frekuensi relatif jenis adalah perbandingan antara frekuensi jenis ke i dan jumlah frekuensi untuk seluruh jenis (Bengen, 2000). Nilai frekuensi tertinggi terdapat di dua transek yaitu di stasiun 2 dan stasiun 3 yaitu pada jenis $R$. mucronata dengan nilai $5 \mathrm{ind} / \mathrm{m}^{2}$ relatifnya $52,63 \%$, sedangkan nilai frekuensi terendah terdapat distasiun 1 transek 2 jenis $B$. cylindrica $0,33 \mathrm{ind} / \mathrm{m}^{2}$ relatifnya $7,69 \%$. Frekuensi jenis mangrove untuk setiap transek dapat dilihat pada (Gambar 5 dan 6).

Secara keseluruhan jenis $R$. mucronata ditemukan pada setiap plot/petak pengamatan. Hal ini menunjukan bahwa jenis ini memiliki penyebaran jenis dan keberadaan yang lebih tinggi jika dibandingkan dengan jenis yang lainnya. Kondisi tersebut terjadi karena spesies ini menyukai daerah pasir berlumpur seperti daerah yang dilokasi penelitan yang memiliki substrat pasir berlumpur (Nybakken, 1998 dalam Ontorael, dkk. 2012). Pada penelitian Iskandar, dkk. (2019) di Desa Arakan, nilai frekuensi tertinggi adalah 23.667 relatifnya
$97.26 \%$. Dengan kondisi substrat yang sama terdapat di Desa Lesah nilai frekuensi tertinggi 1 relatifnya 50\% (Asman, dkk. 2020). Selain itu hasil analisis frekuensi relatif mangrove Parmadi, dkk. (2016) yang dilakukan di kawasan Kuala Idi, Kecamatan Idi Rayeuk, Kabupaten Aceh Timur pada frekuensi mangrove yang paling tinggi yaitu $100 \%$ dikarenakan kondisi substrat pada lokasi penelitian berupa pasir berlumpur. Pada penelitian Jacobs, dkk. (2019) di Desa Lamanggo dan Desa Tope, Kecamatan Biaro nilai frekuensi jenis tertinggi yaitu $100 \mathrm{ind} / \mathrm{m}^{2}$ dengan nilai frekuensi relatif rata-rata $36.01 \%$. Pada penelitian Ontorael, dkk. (2012) di Desa Tarohan Selatan Kecamatan Beo Selatan Kabupaten Kepulauan Talaud, nilai frekuensi tertinggi yaitu $1,5 \mathrm{ind} / \mathrm{m}^{2}$ dengan nilai frekuensi relatif $33 \%$.

Berdasarkan beberapa penelitian menunjukan bahwa nilai frekuensi mangrove dipengaruhi oleh banyaknya suatu jenis yang ditemukan pada setiap kuadran, makin banyak jumlah kuadran yang ditemukan jenis mangrove, maka nilai frekuensi kehadiran mangrove semakin tinggi (Mangindaan, $d k k$. 2012).

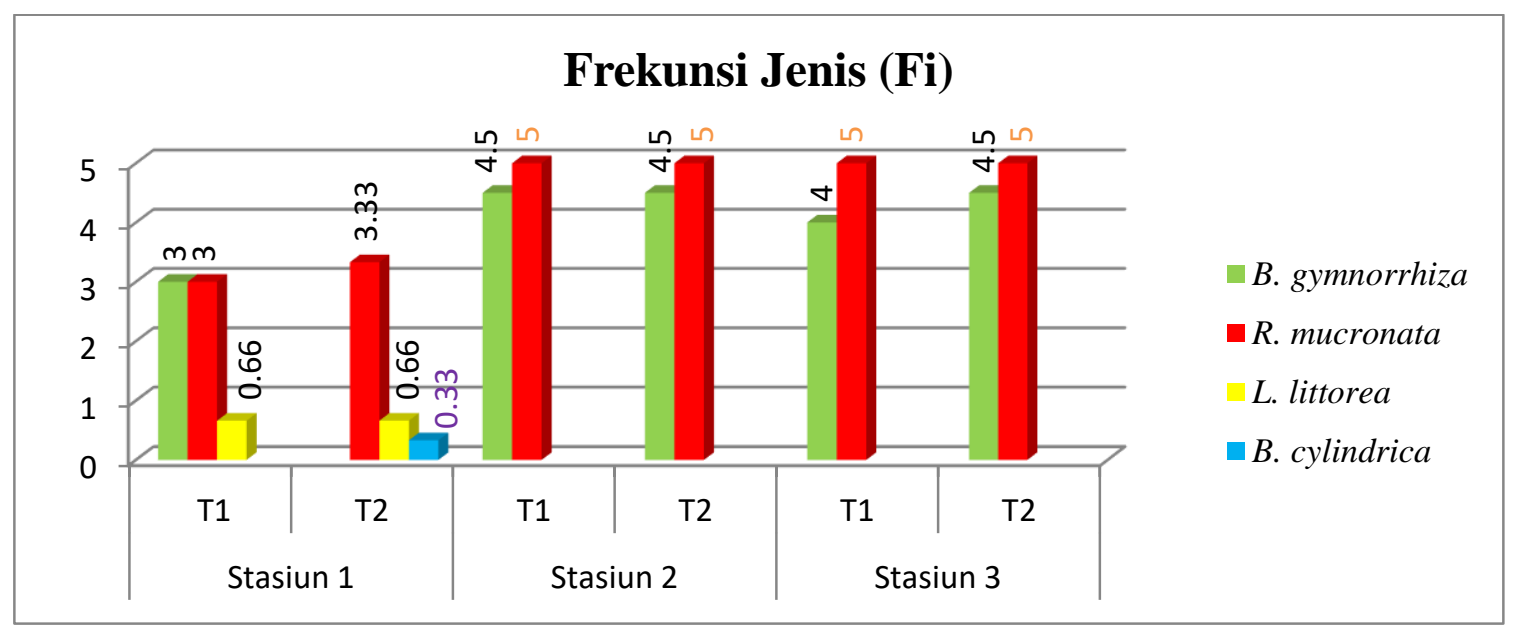

Gambar 5. Frekuensi Jenis (Fi) 


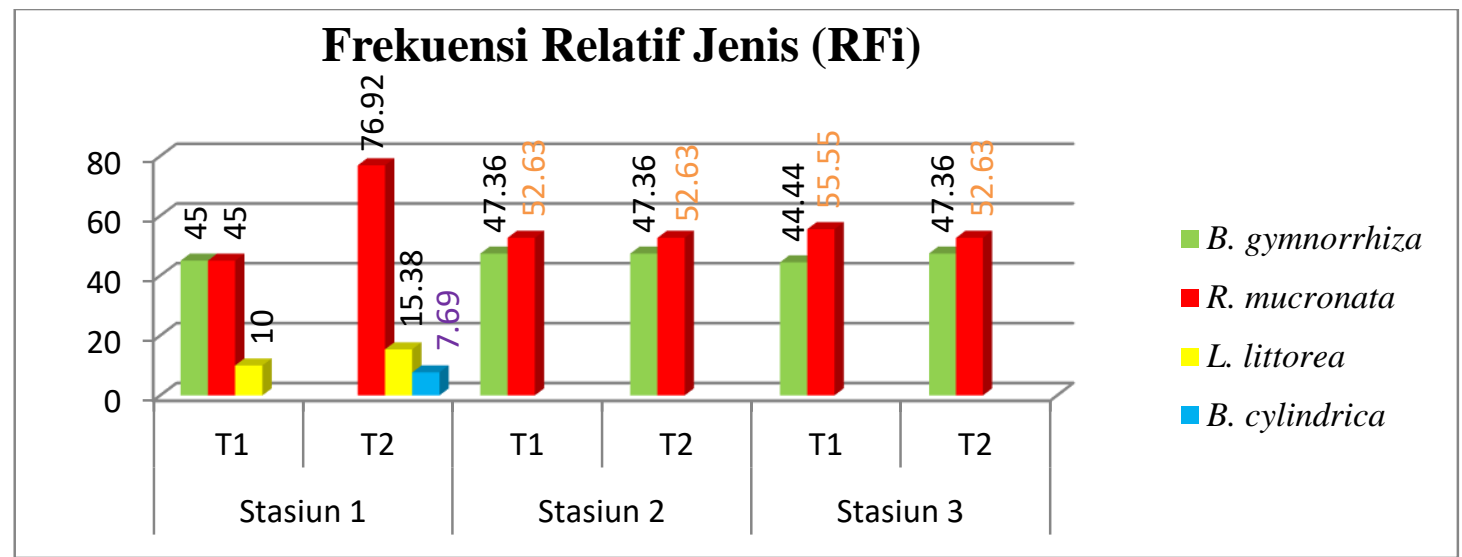

Keterangan warna nilai :

Nilai Tertinggi

Nilai Terendah

Gambar 6. Frekuensi Relatif Jenis (Rfi)

\section{Penutupan Jenis dan Penutupan Relatif Jenis}

Penutupan jenis (Ci) adalah luas penutupan jenis ke-i dalam suatu area sedangkan Penutupan relatif (RCi) merupakan perbandingan antara luas area penutupan jenis ke-i (Ci) dan total luas penutupan untuk seluruh jenis $(\Sigma C)$ (Parmadi, $d k k$. 2016). Nilai penutupan tertinggi terdapat di stasiun 2 transek 1 jenis $B$. gymnorrhiza dengan nilai $3,79 \mathrm{~m}^{2}$ relatfnya $52,21 \%$ sedangkan nilai penutupan terendah terdapat distasiun 1 transek 2 jenis $B$. cylindrica dengan nilai $0,04 \mathrm{~m}^{2}$ relatifnya $0,86 \%$. Penutupan mangrove untuk setiap transek dapat dilihat pada (Gambar 7 dan 8).

Sofian, dkk. (2012) menyatakan bahwa kondisi hutan mangrove yang berhadapan langsung dengan laut sehingga mendapatkan pasang surut air laut sangat mendukung jenis tersebut untuk tumbuh. Pada penelitian Asman, dkk. (2020) di Desa Lesah nilai penutupan tertinggi yaitu $1.83 \mathrm{~m}^{2}$ relatfnya $50.18 \%$. Selain itu penelitian Iskandar, dkk. (2019) di Desa Arakan, nilai penutupan jenis tertinggi yaitu 20.075 relatifnya $69.02 \%$, sedangkan pada penelitian Anthoni, dkk. (2017) didapatkan nilai tertinggi penutupan jenis yaitu 12,06 relatifnya yaitu 65,88. Pada penelitian Jacobs, dkk. (2019) di Desa Lamanggo dan Desa Tope, Kecamatan Biaro nilai penutupan jenis tertinggi yaitu $207.87 \mathrm{~m} 2$, dengan relatif nilai $66.7 \%$. Pada penelitian Bacmid, dkk. (2019) di Kelurahan Alung Banua, Kecamatan Bunaken Kepulauan, Kota Manado didapatkan nilai penutupan jenis tertinggi yaitu10.26 nilai relatifnya $92.63 \%$.

Berdasarkan bebrapa penelitian menunjukan bahwa faktor yang mempengaruhi rendahnya nilai penutupan jenis karena adanya kondisi mangrove yang heterogen (Anthoni, dkk. 2017). Selain itu hal ini disebabkan adanya eksploitasi sumberdaya alam yang dilakukan tanpa memperhitungkan kondisi keseimbangan lingkungan. Menurut Hardin (1968) dalam Yuliasamaya, dkk. (2014), fenomena tersebut merupakan the tragedy of the commons, di mana setiap masyarakat berkeinginan untuk meraih keuntungan maksimal terhadap suatu sumberdaya alam namun pada akhirnya ketersediaan sumberdaya alam tersebut akan habis dan justru berdampak negatif bagi masyarakat yang mengeksploitasi dan masyarakat lainnya. 


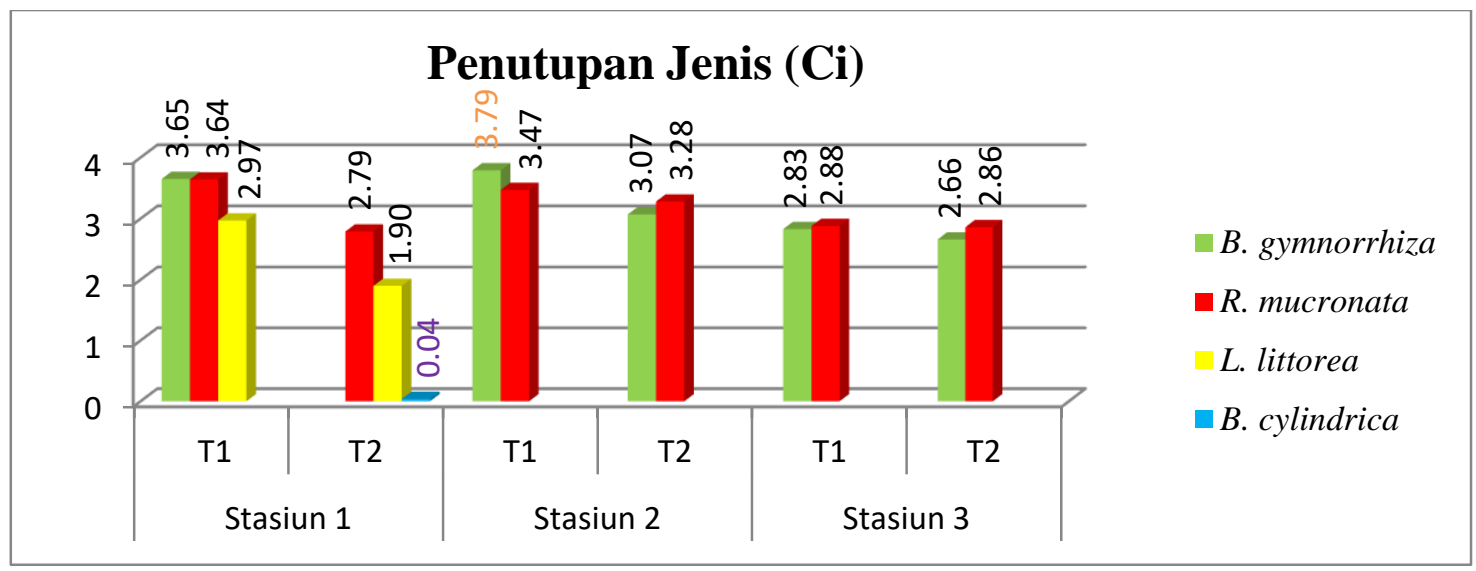

Gambar 7. Penutupan Jenis (Ci)

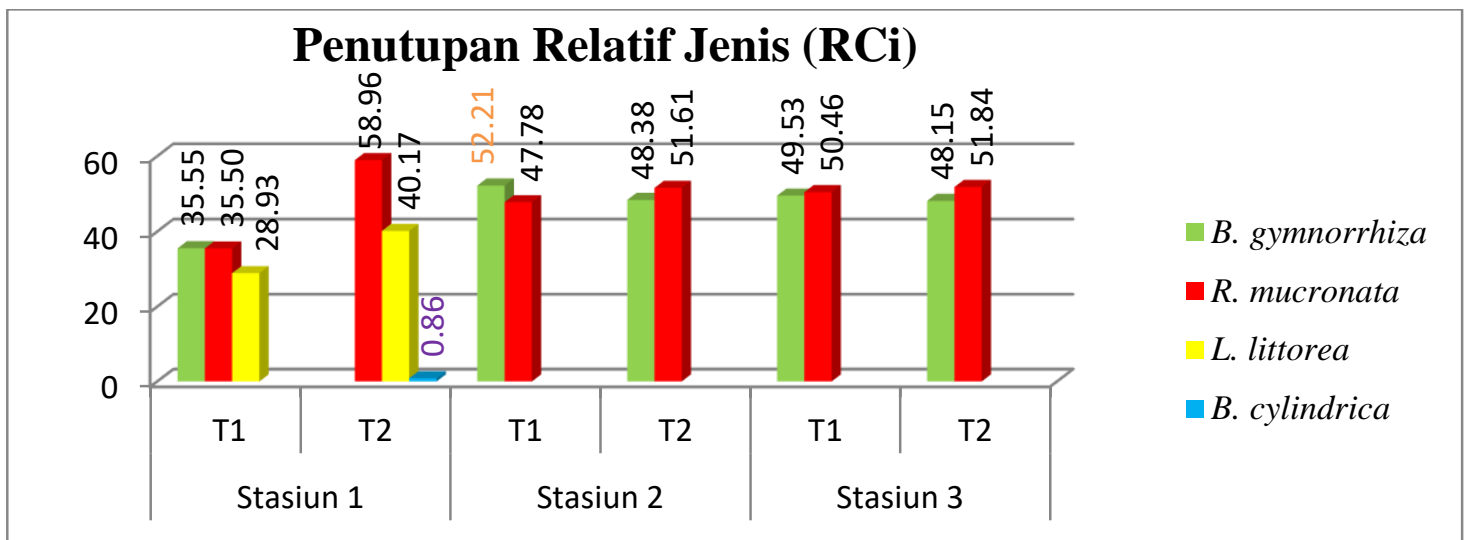

Keterangan warna nilai :

Nilai Tertinggi

Nilai Terendah

Gambar 8. Penutupan Relatif Jenis

\section{Indeks Nilai Penting}

Indeks Nilai Penting (INP) suatu jenis berkisar antara 0\% - 300\%. Nilai Penting ini memberikan suatu gambaran mengenai pengaruh atau peranan suatu jenis tumbuhan mangrove dalam komunitas mangrove. Indeks Nilai Penting tertinggi terdapat di stasiun 1 transek 2 jenis $R$. mucronata dengan nilai $227,72 \%$ dan indeks nilai penting terendah terdapat distasiun 1 transek 2 jenis B. cylindrical dengan nilai $9,91 \%$. Indeks Nilai Penting untuk setiap transek dapat dilihat pada (Gambar 9).

Berdasarkan keseluruhan transek hanya 1 jenis mangrove yang memiliki INP tertinggi dan tersebar di semua transek yaitu R. mucronata, jenis ini memiliki peran cukup penting dalam lingkungan kawasan pesisir
Desa Bone Baru, baik ekologi, biologi maupun ekonomi. Mangrove jenis $R$. mucronata merupakan jenis mangrove yang memiliki bentuk akar tunjang yang dapat membantu mencegah erosi pantai dalam restorasi habitat mangrove yang ada di Desa Bone Baru. Agustini, dkk. (2016), berpendapat bahwa spesies-spesies yang dominan dalam suatu komunitas tumbuhan memiliki indeks nilai penting yang tinggi, sehingga spesies yang paling dominan memiliki indeks nilai penting yang paling besar. Parmadi, dkk. (2016) menyatakan bahwa Perbedaan indeks nilai penting vegetasi mangrove ini dikarenakan adanya kompetisi pada setiap jenis untuk mendapatkan unsur hara dan sinar cahaya matahari pada lokasi penelitian. Selain dari unsur hara dan matahari, faktor lain yang menyebabkan perbedaan kerapatan vegetasi 


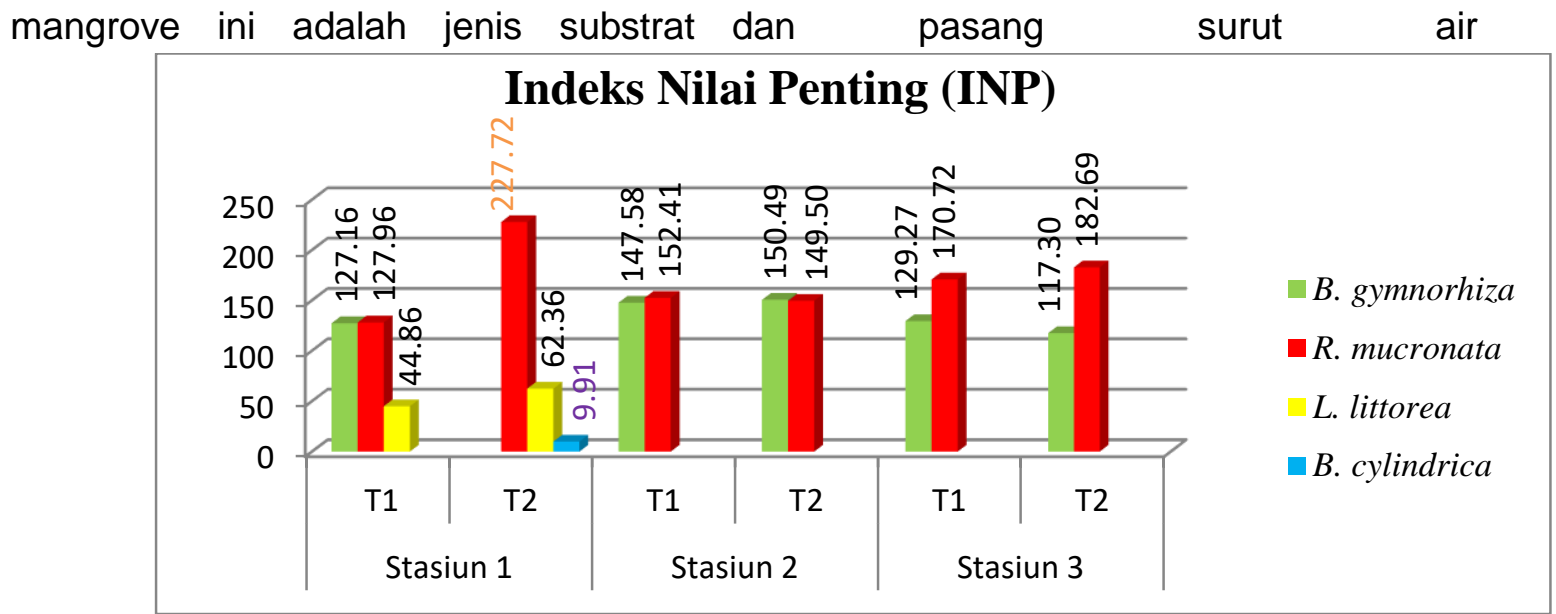

laut.

Keterangan warna nilai :

Nilai Tertinggi

Nilai Terendah

Gambar 9. Indeks Nilai Penting

\section{Indeks keanekaragaman}

Indeks keanekaragaman adalah ukuran kekayaan komunitas dilihat dari jumlah spesies dalam suatu kawasan beserta jumlah individu dari setiap spesies (Kontu, 2014). Nilai indeks keanekaragaman jenis $\left(\mathrm{H}^{\prime}\right)$ stasiun 1 transek 1 sebesar $(0,88)$, transek 2 $(0,32)$ dengan nilai rata-rata 0,6 . Stasiun 2 transek $1(0,69)$, transek $2(0,69)$ dengan nilai rata-rata 0,69 . Stasiun 3 transek $1(0,65)$, transek $2(0,52)$ dengan nilai rata-rata 0,59 . Nilai indeks keanekaragaman tertinggi pada stasiun $2\left(H^{\prime}\right)$ 0,69. Menurut Indriyanto (2006) dalam Agustini, dkk. (2016), keanekaragaman spesies dapat digunakan untuk mengukur stabilitas komunitas, yaitu kemampuan suatu komunitas untuk menjaga dirinya tetap stabil. Indeks keanekaragama untuk setiap transek dapat dilihat pada (Gambar 10).
Menurut (Soegianto, 1994 dalam Lahabu, dkk. 2015) menjelaskan bahwa keanekaragaman jenis digunakan untuk mengukur kemampuan suatu komunitas untuk menjaga dirinya terhadap gangguan dan dapat digunakan untuk mengukur kekayaan komunitas. (Dahuri, 2003 dalam Bessie, dkk. 2013) menyatakan bahwa keanekaragaman ekosistem mangrove terbentuk karena pola zonasi di mana pola ini berkaitan erat dengan faktor lingkungan, seperti tanah (lumpur, pasir, dan gambut), keterbukaan terhadap hempasan gelombang, salinitas, dan pengaruh pasang surut. Hal ini dapat dilihat dari jumlah jenis dalam suatu kawasan semakin banyak jumlah jenis maka semakin tinggi nilai keanekaragaman. (Ludwig dan Reynold, 1988 dalam Lahabu, dkk. 2015).

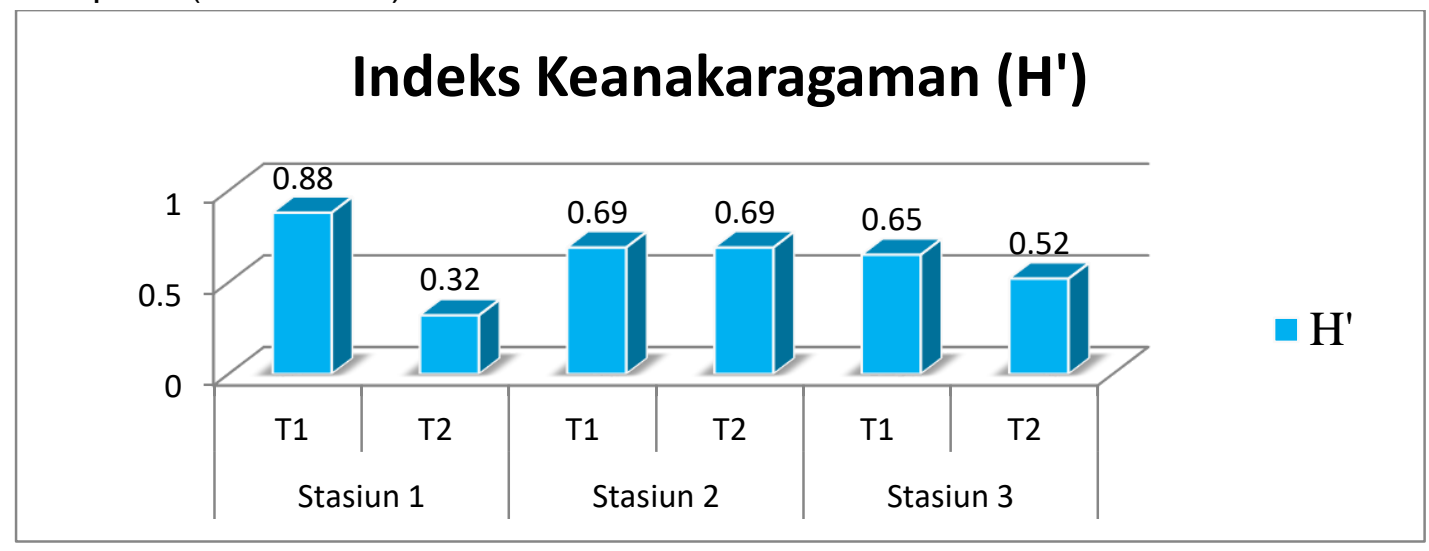

Gambar 10. Indeks Keanekaragaman ( $\left.\mathrm{H}^{\prime}\right)$ 


\section{KESIMPULAN DAN SARAN Kesimpulan}

Berdasarkan hasil penelitian, mangrove di Desa Bone Baru terdapat 4 jenis mangrove, yang terdiri dari, Bruguiera gymnorhiza, Rhizophora mucronata, Lumnitzera littorea dan Bruguiera cylindrica.

Berdasarkan nilai-nilai yang didapat disetiap stasiun menunjukan bahwa nilai tertinggi yang mendominasi adalah jenis Rhizophora mucronata, diduga bahwa pada daerah ini memiliki habitat yang cocok, serta Jenis ini lebih unggul dalam memanfaatkan sumberdaya atau lebih dapat menyesuaikan diri dengan lingkungan setempat dan lebih menguasai habitatnya.

\section{Saran}

Berdasarkan hasil yang diperoleh selama melakukan penelitian, saran saya yaitu sebagai berikut :

1. Diperlukan adanya Pemahaman serta kepedulian dari Pemerintah Daerah Kab. Banggai Laut terhadap kelengkapan data-data mengenai status Hutan Mangrove yang ada di Kab. Banggai Laut.

2. Diperlukan adanya sosialisasi kepada beberapa instansi terkait dan masyarakat sekitar yang berada di Desa Bone Baru terhadap fungsi dari hutan mangrove, disertai kegiatan pengawasan, dan pengendalian langsung dilapangan.

\section{DAFTAR PUSTAKA}

Agustini, N.T., Ta'alidin, Z., Purnama, D. 2016. Struktur Komunitas Mangrove Di Desa Kahyapu Pulau Enggano. Jurnal Enggano Vol 1 No. 1.

Anthoni, A., Schaduw, J.N.W., Sondak, C.F.A. 2017. Persentase Tutupan dan Struktur Komunitas Mangrove Di Sepanjang Pesisir Taman Nasional Bunaken Bagian Utara. Jurnal Pesisir dan Laut Tropis. Vol 2 No.1 : 13-21

Asman, I., Sondak, C.F.A., Schaduw, J.N.W., Kumampung, D.R.H., Ompi, M., Sambali, H. 2020. Struktur Komunitas
Mangrove Di Desa Lesah, Kecamatan Tagulandang, Kabupaten Sitaro. Jurnal Pesisir Dan Laut Tropis Vol 8 No. 2

Bacmid, N.K., Schaduw, J.N.W., Warouw, V. 2019. Kajian Kesesuaian Lahan Ekowisata Mangrove Dimensi Ekologi ( Kasus Pada Pulau Bunaken Bagian Timur, Kelurahan Alung Banua, Kecamatan Bunaken Kepulauan, Kota Manado). Jurnal Pesisir dan Laut Tropis.Vol 7 No. 2

Bengen, D.G. 2000. Sinopsis Ekositem dan Sumberdaya Wilayah Pesisir.Pusat Kajian Sumberdaya Pesisir dan Lautan IPB. Hal. $1: 2$

Bessie, M.D., Schaduw, J.N.W., E. Reppie, M.T. Lasut. 2013. Community Structure Of Mangrove At Marine Tourism Park Of Kupang Bay, East Nusa Tenggara. Aquatic Science \& Management. 3 - $9 \mathrm{Hal}$.

Dharmawan, I.W.E. dan Pramudji. 2014. Panduan Monitoring Status Ekosistem Mangrove. COREMAP-CTI. Pusat Penelitian Oseanografi. Lembaga IImu Pengetahuan Indonesia. $8 \mathrm{Hal}$.

Djamaluddin R. 2018. Mangrove Biologi, Ekologi, Rehabilitas, dan Konservasi. Unsrat Press, Hal. 41:42.

Iskandar, A.T.O., Schaduw, J.N.W., Rumampuk, D.C.N., Sondak, C.F.A., Warouw, V., Rondonuwu, A. 2019. Kajian Kesesuaian Lahan Ekowisata Mangrove Di Desa Arakan Kabupaten Minahasa Selatan Sulawesi Utara. Jurnal Pesisir Laut dan Tropis. Vol 7 No. 1

Jacobs, R., Kusen, J.D., Sondak, C.F.A., Boneka, F.B., Warouw, V., Mingkid W.M. 2019. Struktur Komunitas Ekosistem Mangrove Dan Kepiting Bakau Di Desa Lamanggo Dan Desa Tope, Kecamatan Biaro, Kabupaten Kepulauan Siau, Tagulandang, Biaro. Jurnal Pesisir Dan Laut Tropis. Vol 1 No.1 
Kontu, T. 2014. Struktur Komunitas Mangrove BatuLine Desa Bahoi Kecamatan Likupang Barat Kabupaten Minahasa Utara. Jurnal Pesisir dan Laut Tropis Vol 1 No. 1

Lahabu, Y., Schaduw J.N.W., Windarto, A.B. 2015. Kondisi Ekologi Mangrove Di Pulau Mantehage Kecamatan Wori Kabupaten Minahasa Utara Provinsi Sulawesi Utara. Jurnal Pesisir dan Laut Tropis. Vol 2 No. 1

Mangindaan, P., Wantasen, A., Mandagi, S.V. 2012. Analisis Potensi Sumberdaya Mangrove Di Desa Sarawet, Sulawesi Utara, Sebagai Kawasan Ekowisata. Jurnal Pesisir Dan Laut Tropis. Vol. VIII-2

Noor, y., M. Khazali., I.N.N. Suryadiputra. 2006. Panduan Pengenalan Mangrove Di Indonesia. PHKA/IP, Bogor. 220 Hal.

Ontorael, R., Wantasen, A.S ., Rondonuwu, A.B. 2012. Kondisi Ekologi Dan Pemanfaatan Sumberdaya Mangrove Di Desa Tarohan Selatan Kecamatan Beo Selatan Kabupaten Kepulauan Talaud. Jurnal IImiah Platax Vol. I-1

Parmadi, JC, E.H., Dewiyanti, I., Karina, S. 2016. Indeks Nilai Penting Vegetasi Mangrove Di Kawasan Kuala Idi, Kabupaten Aceh Timur. Jurnal IImiah Mahasiswa Kelautan dan Perikanan Unsyiah. Vol 1 No. 1 : 82-95.

Paulus1, J.H., Pelealu, J., Tulung, M., Gerung, G. 2015. DNA Barcode of a New Species Insect in Mangrove Ecosystem at Likupang Village, North Minahasa Regency, North Sulawesi Province, Indonesia. International Journal of Research in Engineering and Science (IJRES). Vol 3 Issue 5 PP. $46-49$

Paulus, J.J.H., Mantiri, D.M.H., Kepel, R.Ch., Rumampuk, N.D.C., Rori, F., Pandey, E.V., Sinjal, C.A.L. 2020. Studi Non Point Source Kandungan Cadmium Dari Sedimen Mangrove Di Likupang: Dialamatkan Untuk Konservasi Taman
Nasional Bunaken Indonesia. Jurnal IImiah Platax. Vol. 8:(1)

Schaduw, J.N.W. 2019. Struktur Komunitas dan Persentase Penutupan Kanopi Mangrove Pulau Salawati Kabupaten Kepulauan Raja Ampat Provinsi Papua Barat. Majalah geografi indonesia, Vol 33 No.1

Setyawan, A.D., Indrowuryatno, Wiryanto, Winarno, K., Susilowat, A. 2005. Tumbuhan Mangrove Di Pesisir Jawa Tengah: 1. Keanekaragaman Jenis. Jurusan Biologi Fmipa Uns Surakarta. Vol 6 No.2

Sofian, A., Harahap, N., Marsoedi, M. 2012. Kondisi dan Manfaat Langsung Ekosistem Hutan Mangrove Desa Penunggul Kecamatan Nguling Kabupaten Pasuruan. Jurnal ElHayah. Vol 2 No. 2 : 56-63

Sondak, C.F.A. 2015. Estimasi Potensi Penyerapan Karbon Biru (Blue Carbon) Oleh Hutan Mangrove Sulawesi Utara. Jurnal of ASEAN Studies, 1(1): 24-29.

Wantasen, A.S. 2013. Kondisi Kualitas Perairan Dan Substrat Dasar Sebagai Faktor Pendukung Aktivitas Pertumbuhan Mangrove Di Pantai Pesisir Desa Basaan I, Kabupaten Minahasa Tenggara. Jurnal IImiah Platax. Vol. 1: 4

Yuliasamaya, Darmawan, A., Hilmanto, R. 2014. Perubahan Tutupan Hutan Mangrove Di Pesisir Kabupaten Lampung Timur (Mangrove Forest Cover Change Along The Coast Of East Lampung Regency). Jurnal Sylva Lestari. Vol 2 No. 3 : 111-124 Hal. 